MeYneul, G. G. (1959). J. gen. Microbiol. 21, 421-437

\title{
Use of Superinfecting Phage for Estimating the Division Rate of Lysogenic Bacteria in Infected Animals
}

\author{
By G. G. MEYNELL \\ Department of Bacteriology, St Thomas's Hospital Medical School, London, S.E. I
}

SUMMARY: The rate of division of lysogenic bacteria in infected animals can be estimated by superinfecting the bacteria with a suitable mutant of the prophage before inoculation. Since, as shown by other workers, the mutant phage is usually stable and does not multiply during bacterial growth, the proportion of bacteria carrying the mutant steadily falls in a predictable manner in each bacterial generation. Comparison of the proportions of superinfected bacteria present at the start and at the end of a known period therefore gives the number of bacterial generations occurring in a known time. It is assumed that there is no selection either for or against superinfected bacteria.

Mice were inoculated with Escherichia coli strain K12, lysogenized by phage $\lambda \mathrm{b}$ and superinfected by phage $\lambda$ hc. The proportion of superinfected bacteria in the spleen did not usually change in the $30 \mathrm{hr}$. following inoculation. Hence, this strain of bacteria cannot produce viable progeny in the spleen.

The behaviour of the superinfecting phage differed in two ways from that described by previous workers. First, only part of the adsorbed phage was recovered after induction by ultraviolet radiation. Second, the proportion of bacteria which yielded superinfecting phage sometimes fell very rapidly when superinfected overnight cultures were diluted in a medium which allowed bacterial multiplication. This phenomenon is referred to as 'unstable superinfection'.

When mice are injected with Salmonella paratyphi B or S. typhimurium and the number of viable bacteria/mouse are counted at intervals thereafter, the viable count is found to increase far more slowly than when the organisms are growing in nutrient broth (Meynell \& Meynell, 1958, Table 2). This difference might arise in two ways. Either the bacteria are merely dividing more slowly in vivo and the rate of division equals the rate of increase of the viable count; or the bacteria are dividing as fast in vivo as in broth but are at the same time being killed, so that the rate of division is greater than the rate of increase of the viable count. The two possibilities can be distinguished only if bacterial division rate can be measured while bacteria are also being killed. This can now be done by the method described below which has been tested with Escherichia coli administered to mice by intravenous injection and later recovered from the spleen.

The technique is based on observations made by Bertani (1953, 1954), Jacob \& Wollman (1953) and Jacob (1954) on lysogenic bacteria; i.e. bacteria carrying temperate phage in the prophage state (Lwoff, 1953; Bertani, 1958). When a lysogenic bacterium is superinfected with a suitable mutant of its prophage, the mutant enters the bacterium but its subsequent multiplication is usually prevented. Hence, when the superinfected bacterium divides to produce two daughter bacteria (Fig. 1), both contain the original prophage 
but only one contains the superinfecting phage. Similarly, in the second generation all four daughters carry prophage, but again only one carries superinfecting phage. Thus, if each bacterium initially contains one superinfecting phage particle, the proportion of superinfected bacteria halves in each generation. This will still be so if some bacteria die. For example, if there were 1000 superinfected bacteria initially, there would be 2000 in the first generation of which $\frac{1}{2}$ carried the superinfecting phage. If $\frac{3}{4}$ of the bacteria now died, the fraction of superinfected bacteria would still be $\frac{1}{2}(=250 / 500)$.

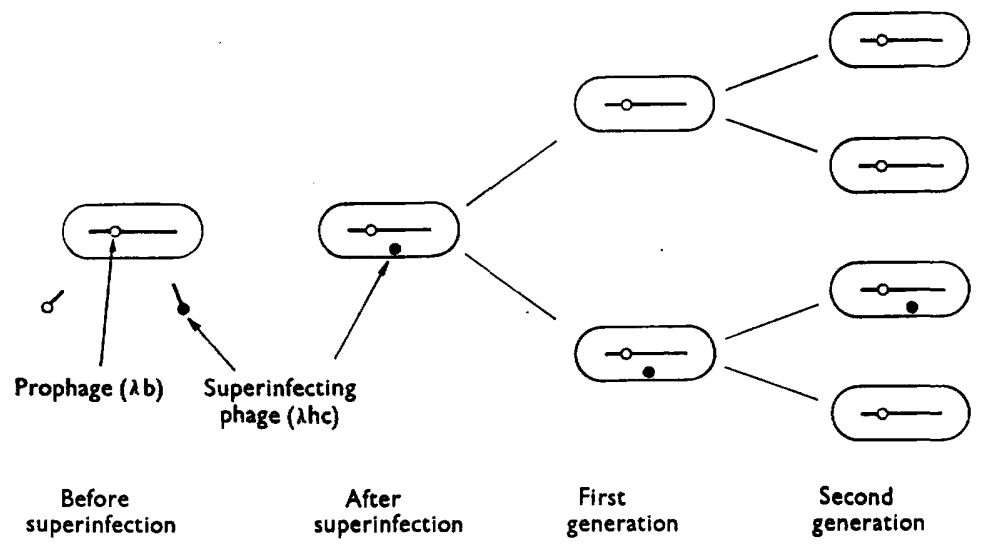

Fig. 1. Distribution of superinfecting phage amongst dividing lysogenic bacteria. Each bacterium carries the prophage of phage $\lambda \mathrm{b}$, which multiplies synchronously with the bacteria. The superinfecting phage $(\lambda \mathrm{hc})$ does not multiply. Hence, if each bacterium initially contains one superinfecting phage particle, the proportion of superinfected bacteria halves in each bacterial generation.

The principle of the method is therefore, first, to inoculate mice with bacteria of which a known proportion is superinfected; and, second, after recovering the organisms from the mouse at a known time after inoculation, to remeasure the proportion of superinfected organisms and deduce the number of generations that have occurred since inoculation. It is assumed that super-infection has no effect on the behaviour of the organism in vivo or on its liability to be killed by the host, and also that the fate of the superinfecting phage is not affected by the time taken for bacterial divisions to occur.

The organism used in these experiments was Escherichia coli strain $\mathrm{K} 12$, lysogenized by phage $\lambda \mathrm{b}$. This phage forms target plaques which are bigger than those of wild-type phage $\lambda$ and has the wild-type host range, since it grows in E. coli strain C 600 but not in E. coli strain CR 63. Lysogenic bacteria of strain $\mathrm{K} 12(\lambda \mathrm{b})$ were superinfected with phage $\lambda$ he, which forms clear plaques and can grow in strain CR63 (Appleyard, McGregor \& Baird, 1956) as well as in strain $\mathrm{C600}$. Strain CR63 is therefore a selective bacterial indicator for the superinfecting phage $\lambda$ he. Both phage $\lambda \mathrm{b}$ and phage $\lambda$ he are normally latent within the superinfected bacterium and in order to determine the proportion of superinfected organisms the phages must be induced to enter the lytic cycle of multiplication by exposure to ultraviolet (u.v.) 
radiation (Lwoff, Siminovitch \& Kjeldgaard, 1950). After irradiation the organisms are plated with strain $\mathrm{CR63}$ and with strain $\mathrm{C} 600$ before lysis occurs. Each induced bacterium yields phage $\lambda b$ and can form a plaque on strain C600. Each induced superinfected bacterium also yields phage $\lambda$ he and therefore can form a plaque on strain CR 63. The proportion of superinfected organisms is then obtained from the ratio of the number of plaques on strain CR63 to the number of plaques on strain $\mathbf{C 6 0 0}$.

\section{METHODS}

Media. The following solid medium was used for colony and plaque counts by the overlay method (Adams, 1959): peptone 2\% (w/v; Evans Medical Supplies Ltd., Ruislip, Middlesex); NaCl $0.5 \%(\mathrm{w} / \mathrm{v})$; agar $1.5 \%(\mathrm{w} / \mathrm{v})$ dissolved in distilled water. After adjustment to $\mathrm{pH} \mathbf{7 \cdot 2}$ by adding $\mathrm{N}-\mathrm{NaOH}$, the medium was sterilized by steaming for 2 periods of $45 \mathrm{~min}$. Before plates were poured, glucose was added to a final concentration of $0.2 \%$ $(w / v)$. Overlays contained $2.5 \mathrm{ml}$. of the medium with the agar decreased to $0 \cdot 6-0.9 \%(w / v)$.

Cultures were also grown in buffered glucose peptone water (BGPW) containing: glucose, $0.1 \%(\mathrm{w} / \mathrm{v})$; peptone $1 \%(\mathrm{w} / \mathrm{v}) ; \mathrm{NaCl} 0.5 \%(\mathrm{w} / \mathrm{v})$; sodium $\beta$-glycerophosphate $3.15 \%(\mathrm{w} / \mathrm{v})$; dissolved in distilled water. The $\mathrm{pH}$ was brought to $7 \cdot 2$ by adding $\mathrm{N}-\mathrm{HCl}$ and the medium finally sterilized by autoclaving at $115^{\circ}$ for $10 \mathrm{~min}$.

Buffer. $\mathrm{M} / 20$ sodium $\beta$-glycerophosphate adjusted to $\mathrm{pH} \mathbf{7 \cdot 2}$ by addition of $\mathrm{N}-\mathrm{HCl}$ and sterilized by autoclaving at $115^{\circ}$ for $10 \mathrm{~min}$.

Bacteria. Stocks of Escherichia coli strain K12 ( $\lambda \mathrm{b})$ and the indicator strains, C600 and CR63, were kept on slopes of Dorset's egg medium at $4^{\circ}$. Plates bearing discrete colonies were prepared for daily use and were also kept at $4^{\circ}$. Cultures in liquid medium were grown overnight at $37^{\circ}$ in screw-capped bottles containing $10 \mathrm{ml}$. buffered glucose peptone water which were rotated on a turntable at $45 \mathrm{rev} . / \mathrm{min}$. After incubation the cultures had a $\mathrm{pH}$ value of 6.7 and contained $c .7 \times 10^{8}$ organisms $/ \mathrm{ml}$. of which not less than $70 \%$ were capable of colony formation. Phage $\lambda$ he was stable in the supernatant fluids of these cultures.

Phage. Stocks of phage $\lambda$ he were made by inoculating overlays with strain CR 63 and about $10^{8}$ plaque-forming particles of the phage. (Hereafter, the term 'phage' is used instead of 'plaque-forming particle'.) Neither the plates nor the overlays contained glucose. After incubation overnight at $37^{\circ}$ the overlays were homogenized in the following medium: buffer, 3 parts; infusion broth, 1 part $1 \%(w / v)$ gelatin, 0.01 part. After removal of bacteria and agar by centrifugation and filtration through a sintered glass filter of maximum pore diameter $1.5 \mu$, the titres of the stocks were $c .2 \times 10^{10}$ phage/ml.

Ultraviolet irradiation. The source was a 20 watt discharge tube (Hanovia Ltd., Slough). Before irradiation, organisms in buffered glucose peptone water were diluted 1/100 or more in buffer; organisms recovered from mice 
were washed as described below. Samples of $5 \mathrm{ml}$. were u.v.-irradiated at room temperature in Petri dishes placed on a rocker $52 \mathrm{~cm}$. below the tube. Irradiation of phage T2 under these conditions caused $99 \%$ inactivation in 55 sec. After irradiation, organisms were incubated in buffered glucose peptone water for $50 \mathrm{~min}$. at $37^{\circ}$ in the dark to prevent reversal of the effect of irradiation (Weigle \& Delbrück, 1951). Escherichia coli strain K12 ( $\lambda$ ), lyses not less than $60 \mathrm{~min}$. after irradiation (Weigle \& Delbrück, 1951).

Preparation of superinfected culture for inoculation. Phage $\lambda$ adsorbs best to Escherichia coli strain $\mathrm{K} 12$ in the stationary phase of growth (Lieb, 1953). Overnight cultures were therefore used for superinfection. The bacterial concentration was first estimated with a nephelometer (Evans Electroselenium Ltd., Bishop's Stortford, Herts). The culture was then brought to $37^{\circ}$ and mixed with the appropriate amount of phage $\lambda$ he for $15 \mathrm{~min}$. More than $99 \%$ of the phage was absorbed in this time, so that the mean number of phage adsorbed/bacterium could be taken as the initial phage concentration/the initial bacterial concentration. The numbers of viable bacteria and the titre of unadsorbed phage were measured in every experiment.

The superinfected culture was usually chilled to $4^{\circ}$, centrifuged and resuspended in enough cold buffer to give $10^{\circ}$ bacteria $/ \mathrm{ml}$. The suspension was kept in an ice bath while each mouse was given $0.3 \mathrm{ml}$. of suspension by injection into a tail vein. When the mice had been injected, the remaining suspension was diluted $1 / 100$ in buffered glucose peptone water at $37^{\circ}$ and samples irradiated immediately, and 20 and $40 \mathrm{~min}$. later, to determine the proportion of superinfected organisms in the inoculum.

Recovery of the organisms from the spleen and determination of the proportion of superinfected organisms. Mice were killed by cervical dislocation. Measured volumes of blood were taken from the right pleural cavity and added to 25 vol. of buffer to stop clotting. Spleens were ground in $10 \mathrm{ml}$. distilled water in Griffith's tissue homogenizers. The spleen suspension was next centrifuged in an angle centrifuge for $13 \mathrm{~min}$. at $3000 \mathrm{~g}$ to separate the organisms from tissue protein which would have absorbed u.v. radiation. The pellets were not compact because of the high density of the original suspension. Most of the supernatant fluid was discarded and the deposit resuspended in buffer and centrifuged again for $5 \mathrm{~min}$. at $3000 \mathrm{~g}$ to give a compact deposit. This was repeated once and the final deposit suspended in $5 \mathrm{ml}$. buffer. After u.v.-irradiation for 90 sec. the suspension was added to $1 \mathrm{ml}$. of 6 times full strength buffered glucose peptone water and incubated as usual before plating. Control experiments showed that the washed suspension contained $70-100 \%$ of the viable organisms present in the spleen before washing, and did not diminish the inactivation of phage $\mathrm{T} 2$ by $\mathrm{u} . \mathrm{v}$. radiation, showing that all tissue protein had been removed.

Mice. The mice belonged to the Glaxo Strong strain and were bred at St Thomas's Hospital Medical School. Either sex was used, provided the weight was at least $23 \mathrm{~g}$. 
RESULTS

Behaviour of superinfected bacteria in vitro

Before the proposed method could be used the optimal conditions for induction by u.v. radiation had to be determined. During these experiments it became clear that the behaviour of phage $\lambda$ he and Escherichia coli strain $\mathrm{K} 12$ ( $\lambda \mathrm{b})$ differed not only from that of phage $\lambda$ gc, another mutant of phage $\lambda$, and the strain of $\mathrm{K} 12(\lambda)$ described by Jacob (1954), but also from that of superinfected strains of Shigella dysenteriae and of Pseudomonas pyocyanea (Aeruginosa) described by Bertani (1954) and by. Jacob \& Wollman (1953), respectively. The first difference found was that only part of the adsorbed phage was recovered after induction by u.v. radiation. The second difference was that the proportion of bacteria from which superinfecting phage could be recovered sometimes decreased very rapidly when the organisms were diluted into fresh medium after superinfection in the stationary phase, a condition referred to here as 'unstable superinfection'. The following sections therefore deal first with stably superinfected organisms, their response to u.v.-irradiation and their relation to the superinfecting phage, and lastly with unstably superinfected organisms.

\section{Stable superinfection}

In most experiments the proportion of bacteria which yielded superinfecting phage after induction did not change during the lag phase. These organisms will be referred to as 'stably superinfected', to distinguish them from superinfected bacteria which inactivated the adsorbed phage during the lag phase.

Induction by ultraviolet irradiation. Stably superinfected bacteria in either the stationary or the logarithmic phase of growth were exposed to u.v.irradiation for various times and the proportion of induced organisms yielding the superinfecting phage then measured (Fig. 2). The proportion of organisms induced in either phase of growth was greatest with an exposure of $90 \mathrm{sec}$. (Fig. 2: points joined by continuous lines). However, the proportion of induced bacteria which yielded the superinfecting phage was constant for all exposures.

Fate of adsorbed phage in stable superinfection. The initial proportion of stably superinfected bacteria was always less than expected from the mean number of phage adsorbed/bacterium. This discrepancy might have arisen because (1) all the phage adsorbed by some of the bacteria might be inactivated while all that adsorbed by the remaining bacteria might be preserved; or (2) some bacteria might be unable to adsorb phage so that all the adsorbed phage was taken up by only a fraction of the bacteria; or (3) the bacteria might be identical in their ability to adsorb phage and each phage particle might have a probability $(<1)$ of being preserved after adsorption. It will be shown below that for each hypothesis, the initial mean number $(N)$ of superinfecting phage preserved/stably superinfected bacterium will be different, so that the hypotheses can be distinguished by estimating $N$. This 
was done by allowing a superinfected culture to multiply and determining the relation between the proportion of superinfected organisms and the number of generations of bacterial growth.

Figure 3 shows the result of this experiment and also the curves predicted by the first and third hypotheses given above. All the curves predicted for $N>1$ have the same general shape, being 'multi-hit' curves of the type ' 1 hit on each of $m$ sites' (Atwood \& Norman, 1949), the number of 'sites' in this system being $N$. Each curve has a shoulder because an appreciable number of bacteria each contain more than 1 superinfecting phage particle initially so that the proportion of superinfected organisms falls by less than half

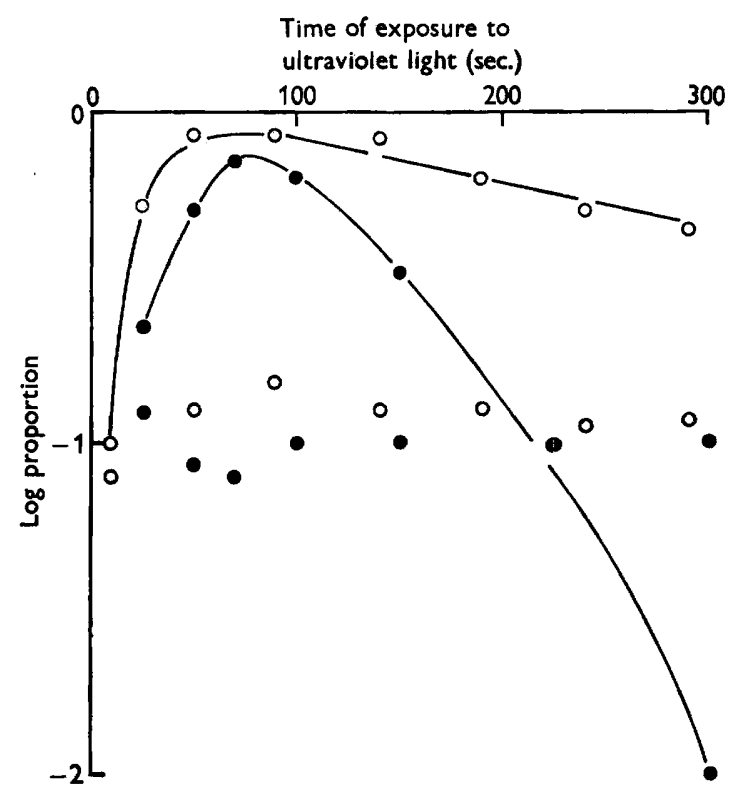

Fig. 2. Effect of time of exposure to ultraviolet radiation on the proportion of organisms induced (points joined by a continuous line) and the proportion of induced organisms yielding superinfecting phage (unjoined points) in either stationary phase (- -) or logarithmic phase (-O-) cultures. The proportion of induced organisms yielding superinfecting phage is constant, regardless of the proportion of organisms induced.

in each of the first few generations. However, after a number of generations each superinfected bacterium contains only 1 superinfecting phage particle so that the curve becomes linear with slope corresponding to a halving of the proportion of superinfected organisms in each generation. The number of generations required to reach this stage will increase as $N$ increases, so that the larger $N$ becomes, the wider will be the shoulder of the curve. The value of $N$ is obtained from such a curve by extrapolating the linear part to the left until it intersects the ordinate for the end of the lag phase. The point of intersection corresponds to the sum of $\log N+$ the logarithm of the initial proportion of stably superinfected bacteria. The reason is that the straight line obtained by extrapolation is that which would have been observed if, 
instead of having a certain initial number of bacteria each containing a mean of $N$ particles, there had been initially $N$ times as many bacteria each containing only 1 superinfecting phage particle. Since the initial proportion of stably superinfected bacteria is known by experiment, the point of intersection with the ordinate provides an estimate of $N$ and enables the three hypotheses given above to be distinguished.

In the experiment shown in Fig. 3, the mean number of phage adsorbed/ bacterium (whether superinfected or not) was $2(\log =0 \cdot 3)$ so that the expected proportion of superinfected bacteria was $0 \cdot 87$. However, the observed proportion was $0 \cdot 36(\log =\overline{\mathbf{I}} \cdot 56)$. (Logarithms of numbers less than 1 are written with a negative characteristic and a positive mantissa. Thus, $\log _{10}$ of $0 \cdot 2$ is not written as -0.7 but as $\bar{I} \cdot 3$, signifying $-1+0.3$.) If the first hypothesis is valid and each stably superinfected bacterium preserved all the phage it adsorbed, $N=$ mean number of phage adsorbed/bacterium, divided by the proportion of bacteria adsorbing phage $=2 / 0 \cdot 87=2 \cdot 3(\log =0 \cdot 36)$. The

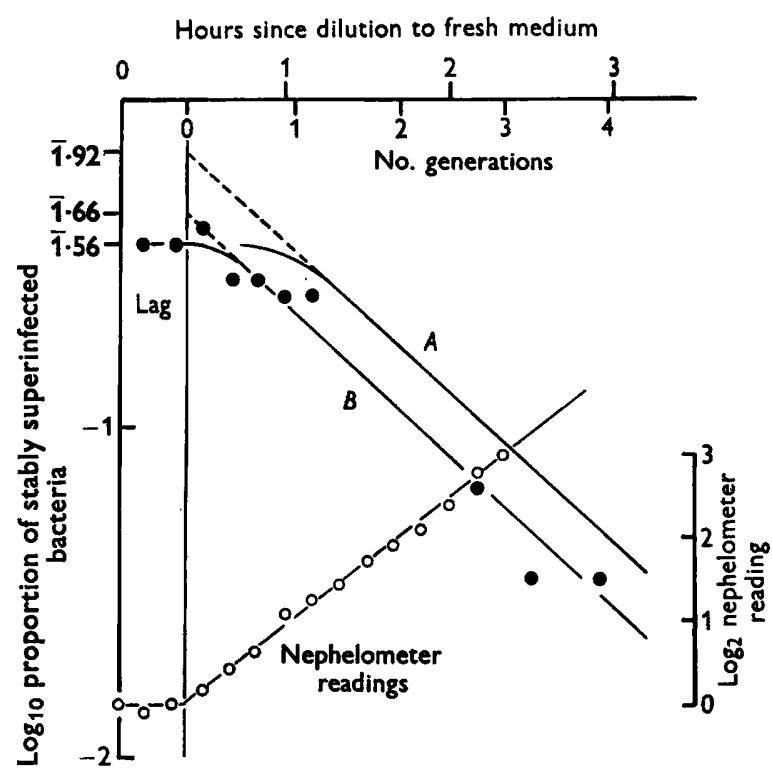

Fig. 3. The proportion of stably superinfected bacteria in the first four generations after superinfection. The degree of bacterial multiplication was measured nephelometrically. The points are plotted at the bottom of the figure against the time scale in $\mathrm{hr}$. on the abscissa and the scale on the right of the figure giving $\log _{2}$ of the nephelometer readings. The latter scale gave the number of generations which was then plotted on the abscissa against the corresponding time in $\mathrm{hr}$. The mean generation time was 40 min.

Curves $A$ and $B$ (continuous lines) are the curves predicted by the 1st and 3rd hypotheses discussed in the Text for the relation between the log proportion of stably superinfected bacteria and the number of generations. The points lie on Curve $B$ and not on Curve $A$. The mean number of phage adsorbed per bacterium was 2 . The probability per adsorbed particle of being preserved was $0 \cdot 23$.

The dashed lines are produced by extrapolating the descending linear portions of Curves $A$ and $B$ to the left until they intersect the ordinate for the end of the lag phase. The logarithms of the points of intersection are I.92 (Curve $A$ ) and $\bar{I} \cdot 66$ (Curve $B$ ) respectively, as shown on the ordinate for the beginning of the lag phase. 
curve predicted on this hypothesis (Curve $\mathbf{A}$ in Fig. 3) therefore extrapolates to a point whose logarithm is $\bar{I} \cdot 92=0.36+\bar{T} \cdot 56(=\log N+$ the logarithm of the initial proportion of stably superinfected bacteria). The observed points clearly do not lie on this line and the first hypothesis is therefore excluded.

The second hypothesis is that $36 \%$ of the bacteria adsorbed all the superinfecting phage. The mean number of phage adsorbed/bacterium was 2 so that $N$ now equals $2(1 / 0 \cdot 36)=5 \cdot 6$. The predicted curve will be even farther to the right of the observed points in Fig. 3 than Curve $A$ because $N$ is larger (5.6 compared with 2-3). This hypothesis is thus also excluded.

The third hypothesis is that each particle had a constant probability $(<1)$ of being preserved after adsorption and the expected curve is calculated as follows. On this hypothesis, $m$, the initial mean number of phage preserved/ bacterium (whether stably superinfected or not) is obtained from the initial proportion of stably superinfected bacteria by applying the first term of the Poisson series in the usual way (Adams, 1959); i.e. 0.36 $=1-e^{-m}$ giving $m=0 \cdot 45$. Therefore, $N$, the initial mean number of phage preserved/stably superinfected bacterium $=0 \cdot 45(1 / 0 \cdot 36)=1 \cdot 25(\log =0 \cdot 1)$. The predicted curve (curve $B$ in Fig. 3) therefore appears to arise from a point whose logarithm is $\mathrm{I} \cdot 66=0 \cdot 1+\mathrm{T} \cdot 56(=\log N$ on this hypothesis $+\log$ of the initial proportion of stably superinfected bacteria). Curve B in Fig. 3 is clearly in good agreement with the observations.

Hence, it appears that the bacteria were not heterogeneous in their ability to absorb or to destroy superinfecting phage, each particle of which must have had a constant small probability of being preserved after adsorption. The value of this probability in the above experiment was $0.23(=0.45 /$ $2=$ mean number of phage preserved/mean number of phage adsorbed).

\section{Distribution of superinfecting phage amongst dividing bacteria}

Figure 3 showed that the preserved fraction of adsorbed phage is distributed amongst the dividing bacteria for at least 4 generations in the expected manner. Fig. 4 shows the result of an experiment of the same kind in which the bacteria passed through 18 generations. Up to the 10th generation the points agree well with the predicted curve obtained in the same way as Curve B in Fig. 3. After the 10th generation, however, the proportion of superinfected bacteria became constant, indicating that the phage was multiplying synchronously with the bacteria. The explanation almost certainly was that the superinfecting phage lysogenized about $1 / 1000$ of the original bacteria which multiplied like the rest of the bacterial population but were not detected until their number exceeded the number of bacteria carrying non-multiplying superinfecting phage.

\section{Unstable superinfection}

Figure 5 shows the changes in viable count and in the proportion of organisms yielding superinfecting phage after induction when an unstably superinfected overnight culture was diluted $1 / 100$ in buffered glucose peptone water at $37^{\circ}$ after the $15 \mathrm{~min}$. period allowed for phage adsorption. Half the bacteria 
died in the first $20 \mathrm{~min}$. but the proportion of organisms which yielded superinfecting phage fell about 25-fold. Fig. 5, Curve B, also shows that the proportion of bacteria which yielded superinfecting phage only fell by half when part of the same culture was centrifuged at the end of the period allowed for phage adsorption, resuspended in buffer at $18^{\circ}$ and placed in the refrigerator at $4^{\circ}$. This suggests that the phage disappeared only when the bacteria were placed in a medium which allowed bacterial multiplication. This conclusion was confirmed by the results given in Table 1 which show: (1) that the superinfecting phage was unstable when the bacteria were diluted in fresh medium immediately after superinfection (Sample 1); (2) that the phage did not disappear when the superinfected culture was not diluted (Sample 2); (3) that holding the superinfected culture at $18^{\circ}$ for $30 \mathrm{~min}$. before incubation at $37^{\circ}$ did not result in stable superinfection (Sample 3 ).

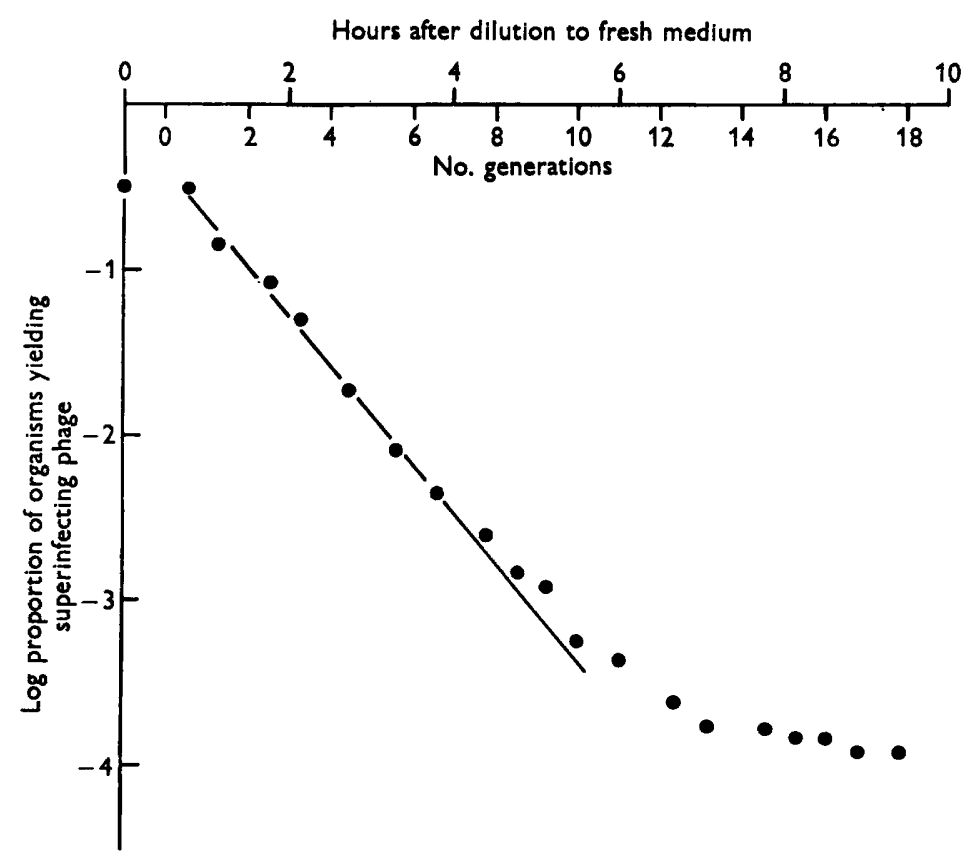

Fig. 4. The proportion of stably superinfected bacteria in the first 18 generations after superinfection. The observations agree well with the predicted curve until the 10th generation. Thereafter the proportion tends to become constant, presumably owing to the multiplication of those bacteria of the superinfected culture which became lysogenized. The mean generation time was 30 min.; the mean number of superinfecting phage adsorbed per bacterium was 3.5 ; and the probability per adsorbed particle of being preserved was $0 \cdot 1$.

The cause of the instability was not established but was probably associated with the state of the bacteria at the time of superinfection, since the degree of instability varied greatly in different experiments performed under apparently identical conditions. It was established that the degree of instability was the same when the mean number of phage adsorbed was either 
4.5 or 0.09 , and was decreased when the overnight culture was aerated in buffer $+1 \%(\mathrm{w} / \mathrm{v})$ glucose for $100 \mathrm{~min}$. before superinfection. The disappearance of the superinfecting phage was not accompanied by induction of the superinfected bacteria.

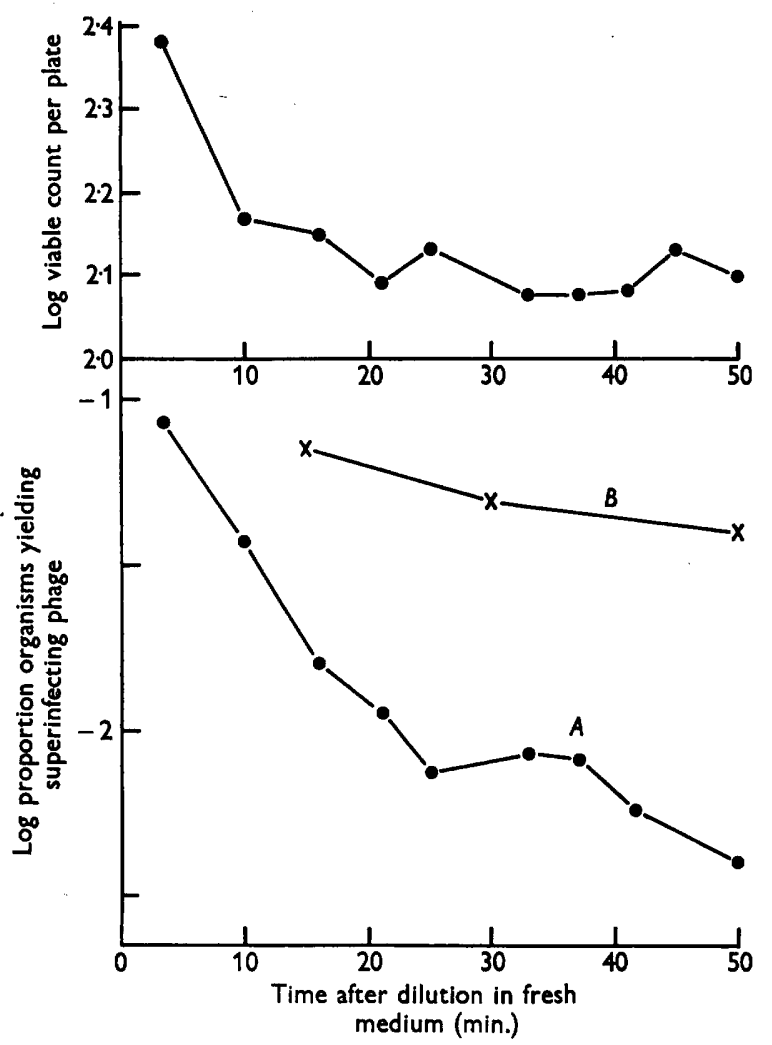

Fig. 5. Behaviour of unstably superinfected organisms during the lag phase. The viable count did not change during the adsorption period of $15 \mathrm{~min}$. The upper curve shows that half the bacteria died after dilution in buffered glucose peptone water at $37^{\circ}$ and that the proportion of bacteria yielding superinfecting phage after induction fell 25-fold (Curve $A$ in the lower half of the Figure). Curve $\mathbf{B}$ shows that more superinfecting phage was preserved when part of the same culture was transferred to buffer at $18^{\circ}$ after superinfection and then placed in the refrigerator.

\section{Behaviour of superinfected bacteria in vivo}

Each mouse received about c. $2.5 \times 10^{8}$ organisms by intravenous injection and about $10 \%$ of the mice died in the $6 \mathrm{hr}$. following inoculation.

Fate of organisms after intravenous injection. The viable count in the blood fell very rapidly after inoculation of the organisms; most blood cultures were sterile after $30 \mathrm{~min}$., and when positive never yielded more than 1/1000 of the initial count expected on the assumption that the inoculum was evenly distributed in a blood volume of $5 \mathrm{ml}$. As blood cultures did not again become positive, the organisms were presumed to be confined to the cells of the reticulo-endothelial system almost from the start of the infection. 
The spleen was chosen for these experiments since it contained as many organisms as the liver but, after homogenization, yielded far less tissue protein to be removed before u.v. irradiation. Figure 6 shows that the number of viable organisms recovered from the spleen was rarely more than $1 / 100$ of that inoculated and rapidly decreased in the first $12 \mathrm{hr}$. after inoculation. After that time, the viable count changed very little, suggesting that the viable organisms recovered in this period might be mutants which were better able to survive in the spleen than the rest of the inoculated population. Therefore, 27 clones, isolated from infected spleens 1 day after inoculation, were tested by re-inoculation into mice. In the first $5 \mathrm{hr}$. after inoculation these organisms survived no better in the spleen than organisms of the original culture and were, therefore, not mutants of increased resistance.

\section{Table 1. Behaviour of an unstably superinfected culture under various conditions}

An overnight culture of Escherichia coli strain $\mathrm{K} 12(\lambda \mathrm{b})$ was superinfected with phage $\lambda$ he, the mean number of phage adsorbed/bacterium being 1.6. The culture was then diluted in three ways as shown by the second column below.

\begin{tabular}{|c|c|c|c|}
\hline Sample no. & Treatment after superinfection & $\begin{array}{l}\text { Time between } \\
\text { dilution and } \\
\text { irradiation } \\
\text { (min.) }\end{array}$ & $\begin{array}{l}\text { Proportion of } \\
\text { organisms } \\
\text { yielding super- } \\
\text { infecting phage }\end{array}$ \\
\hline 1 & $\begin{array}{l}\text { Immediately diluted } \\
1 / 100 \text { in BGPW* at } 37^{\circ}\end{array}$ & $\begin{array}{r}\mathbf{0} \\
\mathbf{3 0}\end{array}$ & $\begin{array}{l}1.8 \times 10^{-2} \\
1.33 \times 10^{-4}\end{array}$ \\
\hline 2 & $\begin{array}{l}\text { Kept at } 37^{\circ} \text { for } 1 \mathrm{hr} \text {. } \\
\text { and then diluted } 1 / 100 \\
\text { in BGPW at } 37^{\circ}\end{array}$ & $\begin{array}{r}\mathbf{0} \\
\mathbf{3 0}\end{array}$ & $\begin{array}{l}1.1 \times 10^{-2} \\
1.25 \times 10^{-4}\end{array}$ \\
\hline $\mathbf{3}$ & $\begin{array}{l}\text { Diluted } 1 / 100 \text { in } B G P W \\
\text { at } 18^{\circ} \text { and after } 30 \mathrm{~min} \text {. } \\
\text { warmed to } 37^{\circ}\end{array}$ & $\begin{array}{r}\mathbf{0} \\
\mathbf{3 0} \\
\mathbf{5 0}\end{array}$ & $\begin{array}{l}1.65 \times 10^{-2} \\
3.08 \times 10^{-8} \\
5.9 \times 10^{-4}\end{array}$ \\
\hline
\end{tabular}

\section{Changes in the proportion of superinfected bacteria after inoculation}

A total of 53 mice were injected with superinfected bacteria in 7 experiments. The results of 4 experiments with 38 mice are given in Tables $2-5$ and those from the two of the largest experiments (Tables 2,3) are also shown in Fig. 7.

The proportion of superinfected organisms in the spleen usually did not change in the $30 \mathrm{hr}$. following inoculation although it occasionally decreased about 4 -fold. This finding suggested that in most mice the viable organisms recovered from the spleen had not divided since the time of inoculation.

Tables 2-5 also show that the proportion of superinfected organisms in the spleen was always greater than in the inoculum, notably in the experiment shown in Table 5; for this reason no attempt was made to calculate the number of generations of growth. There were two possible explanations for this discrepancy. First, the spleen may have preferentially removed superinfected organisms from the blood. Second, some of the inoculated organisms might have been unstably superinfected. There was always a short delay before 
u.v.-irradiation of the inoculum; this might have allowed these organisms to enter the lag phase and to inactivate some of the superinfecting phage. No inactivation would be expected to occur after the organisms had been injected

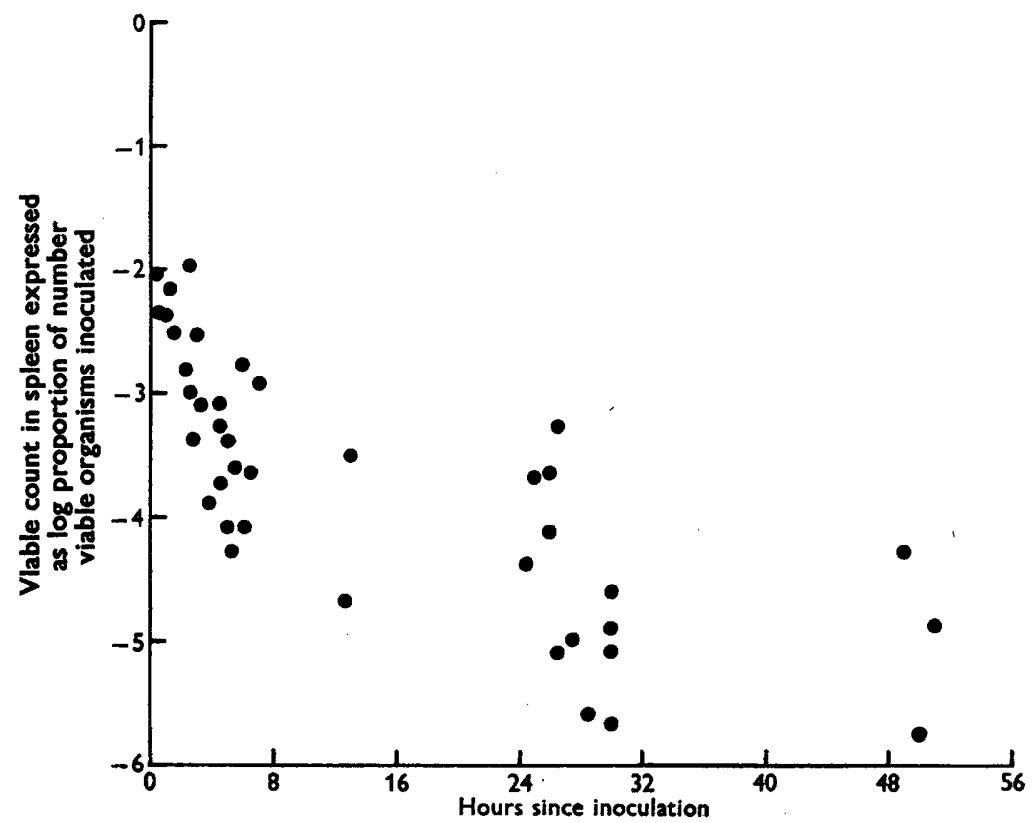

Fig. 6. The number of viable organisms per spleen at various times after inoculation expressed as the log proportion of the number inoculated. The points, each of which gives the count on one spleen, come from unpublished experiments as well as from Tables 2-5. The number of viable organisms inoculated was $c .2 .5 \times 10^{8}$ per mouse.

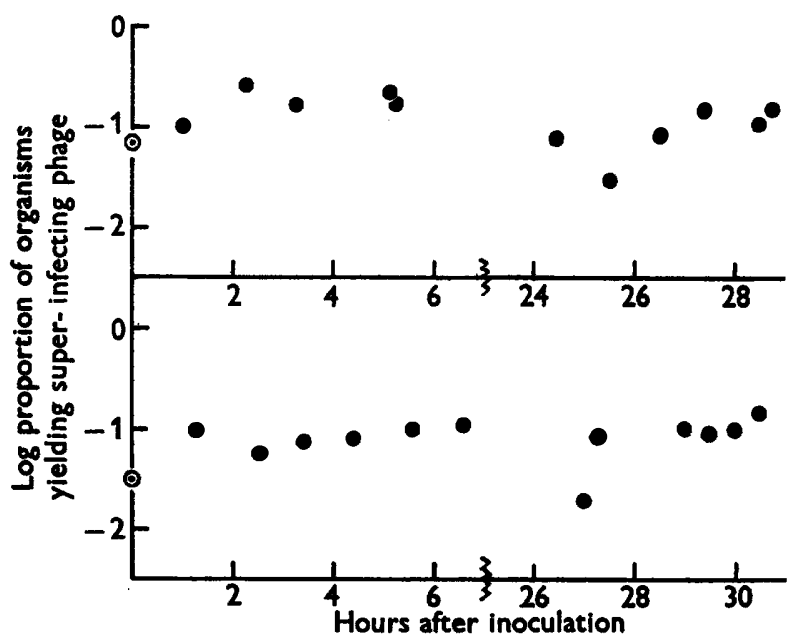

Fig. 7. The proportion of organisms yielding superinfecting phage at various times after inoculation in the experiments shown in Table 2 (upper part of Figure) and Table 3. The points on the ordinate give the average proportion of organisms in the inoculum which yielded superinfecting phage. 
Tables 2-5. The number of viable organisms recovered from the spleen at various times after inoculation and the corresponding proportion of organisms yielding superinfecting phage

Each Table also gives $m$, the mean number of superinfecting phage adsorbed per bacterium, and $p$, the probability per adsorbed particle of being preserved, calculated for the inoculum according to the third hypothesis discussed in the text.

$$
\text { Table 2. } m=2.5 ; p=0.02
$$

\begin{tabular}{|c|c|c|c|c|c|}
\hline \multirow{2}{*}{$\begin{array}{l}\text { Source of } \\
\text { sample }\end{array}$} & \multirow{2}{*}{$\begin{array}{l}\text { Time between } \\
\text { inoculation } \\
\text { and sampling }\end{array}$} & \multirow{2}{*}{$\begin{array}{c}\text { No. viable } \\
\text { organisms } \\
\text { in spleen }\end{array}$} & \multicolumn{2}{|c|}{ No. plaques* counted on } & \multirow{2}{*}{$\begin{array}{c}\text { Proportion of } \\
\text { organisms } \\
\text { yielding } \\
\text { superinfecting } \\
\text { phage* }\end{array}$} \\
\hline & & & CR63 & C600 & \\
\hline $\begin{array}{l}\text { Inoculum } \\
\text { diluted in } \\
\text { BGPW } † \text { at } \mathbf{3 7}\end{array}$ & $\begin{array}{l}2 \mathrm{~min} . \\
20 \mathrm{~min} . \\
\text { y }^{\circ} 40 \mathrm{~min} .\end{array}$ & - & $\begin{array}{l}312 \\
340 \\
391\end{array}$ & $\begin{array}{l}113 \\
144 \\
144\end{array}$ & $\begin{array}{l}0.055 \\
0.047 \\
0.054\end{array}$ \\
\hline $\begin{array}{c}\text { Mice given } \\
2 \cdot 76 \times 10^{8} \\
\text { organisms }\end{array}$ & $\begin{array}{l}1.1 \mathrm{hr} \text {. } \\
2.3 \mathrm{hr} \text {. } \\
3.3 \mathrm{hr} \text {. } \\
5 \cdot 1 \mathrm{hr} \text {. } \\
5.3 \mathrm{hr} \text {. } \\
24 \cdot 4 \mathrm{hr} \text {. } \\
25.5 \mathrm{hr} \text {. } \\
26.5 \mathrm{hr} \text {. } \\
27 \cdot 4 \mathrm{hr} \text {. } \\
28.5 \mathrm{hr} \text {. } \\
28.7 \mathrm{hr} \text {. }\end{array}$ & $\begin{array}{l}1.1 \times 10^{6} \\
4.2 \times 10^{5} \\
2.1 \times 10^{5} \\
1.8 \times 10^{5} \\
1.4 \times 10^{4} \\
1.2 \times 10^{4} \\
1.4 \times 10^{5} \\
2 \cdot 3 \times 10^{8} \\
3 \times 10^{8} \\
6.8 \times 10^{2} \\
7.1 \times 10^{3}\end{array}$ & \begin{tabular}{|r|}
125 \\
101 \\
748 \\
351 \\
262 \\
187 \\
162 \\
23 \\
42 \\
11 \\
53
\end{tabular} & $\begin{array}{r}115 \\
\mathbf{3 7 2} \\
\mathbf{2 3 4} \\
160 \\
\mathbf{2 4 0} \\
\mathbf{4 4 7} \\
\mathbf{1 0 6 2} \\
\mathbf{5 8} \\
\mathbf{7 2} \\
13 \\
\mathbf{5 2}\end{array}$ & $\begin{array}{l}0 \cdot 109 \\
0 \cdot 272 \\
0 \cdot 16 \\
0 \cdot 225 \\
0 \cdot 218 \\
0 \cdot 076 \\
0 \cdot 029 \\
0 \cdot 079 \\
0 \cdot 145 \\
0 \cdot 11 \\
0 \cdot 13\end{array}$ \\
\hline
\end{tabular}

* The volume of suspension plated with strain CR 63 often differed from that plated with strain C600. Consequently, division of the number of plaques does not always yield the proportion shown in the last column.

+ BGPW = buffered glucose peptone water

Table 3. $m=1 \cdot 75 ; p=0.017$

\begin{tabular}{|c|c|c|c|c|c|}
\hline \multirow{2}{*}{$\begin{array}{l}\text { Source of } \\
\text { sample }\end{array}$} & \multirow{2}{*}{$\begin{array}{l}\text { Time between } \\
\text { inoculation } \\
\text { and sampling }\end{array}$} & \multirow{2}{*}{$\begin{array}{l}\text { No. viable } \\
\text { organisms } \\
\text { in spleen }\end{array}$} & No. plaqu & unted on & \multirow{2}{*}{$\begin{array}{l}\text { Proportion } \\
\text { of organisms } \\
\text { yielding } \\
\text { superinfecting } \\
\text { phage }\end{array}$} \\
\hline & & & CR 63 & $\mathrm{C} 600$ & \\
\hline $\begin{array}{l}\text { Inoculum } \\
\text { diluted in } \\
\text { BGPW* at } 37\end{array}$ & $\begin{array}{l}2 \mathrm{~min} . \\
20 \mathrm{~min} . \\
y^{\circ} 40 \mathrm{~min} .\end{array}$ & - & $\begin{array}{l}664 \\
645 \\
951\end{array}$ & $\begin{array}{l}204 \\
195 \\
352\end{array}$ & $\begin{array}{l}0.0822 \\
0.0832 \\
0.0278\end{array}$ \\
\hline $\begin{array}{l}\text { Mice given } \\
2 \cdot 4 \times 10^{8} \\
\text { organisms }\end{array}$ & $\begin{array}{l}1.3 \mathrm{hr} \text {. } \\
2.5 \mathrm{hr} \text {. } \\
3.4 \mathrm{hr} \text {. } \\
4.4 \mathrm{hr} \text {. } \\
5.6 \mathrm{hr} \text {. } \\
6.6 \mathrm{hr} \text {. } \\
27 \mathrm{hr} \text {. } \\
27.3 \mathrm{hr} \text {. } \\
29 \mathrm{hr} \text {. } \\
29.5 \mathrm{hr} \text {. } \\
30 \mathrm{hr} \text {. } \\
30.5 \mathrm{hr} \text {. }\end{array}$ & $\begin{array}{c}7 \cdot 8 \times 10^{5} \\
3.4 \times 10^{5} \\
2 \times 10^{5} \\
2.2 \times 10^{5} \\
- \\
5.5 \times 10^{4} \\
- \\
- \\
- \\
-\end{array}$ & \begin{tabular}{|r|}
$\mathbf{1 2 0}$ \\
$\mathbf{5 0 7}$ \\
$\mathbf{7 5 1}$ \\
$\mathbf{7 0 3}$ \\
$\mathbf{3 6 1}$ \\
$\mathbf{7 3 8}$ \\
$\mathbf{6 7}$ \\
$\mathbf{1 0}$ \\
$\mathbf{2 0}$ \\
$\mathbf{9}$ \\
$\mathbf{1 3}$ \\
$\mathbf{2 1}$ \\
\end{tabular} & \begin{tabular}{r|}
125 \\
45 \\
336 \\
334 \\
429 \\
751 \\
412 \\
60 \\
85 \\
40 \\
48 \\
56
\end{tabular} & $\begin{array}{l}0.096 \\
0.0565 \\
0.074 \\
0.07 \\
0.099 \\
0.115 \\
0.019 \\
0.081 \\
0 \cdot 097 \\
0 \cdot 093 \\
0 \cdot 10 \\
0.145\end{array}$ \\
\hline
\end{tabular}

* BGPW = buffered glucose peptone water. 
Table 4. $m=4 \cdot 8 ; p=0.025$

\begin{tabular}{|c|c|c|c|c|c|}
\hline \multirow{2}{*}{$\begin{array}{l}\text { Source of } \\
\text { sample }\end{array}$} & \multirow{2}{*}{$\begin{array}{l}\text { Time between } \\
\text { inoculation } \\
\text { and sampling }\end{array}$} & \multirow{2}{*}{$\begin{array}{c}\text { No. viable } \\
\text { organisms } \\
\text { in spleen }\end{array}$} & \multicolumn{2}{|c|}{ No. plaques counted on } & \multirow{2}{*}{$\begin{array}{c}\text { organisms } \\
\text { yielding } \\
\text { superinfecting } \\
\text { phage }\end{array}$} \\
\hline & & & CR 63 & C600 & \\
\hline $\begin{array}{l}\text { Inoculum } \\
\text { diluted in } \\
\text { BGPW* at } \\
37^{\circ}\end{array}$ & $\begin{array}{l}2 \mathrm{~min} . \\
20 \mathrm{~min} . \\
40 \mathrm{~min} .\end{array}$ & - & $\begin{array}{l}497 \\
520 \\
262\end{array}$ & $\begin{array}{l}222 \\
915 \\
146\end{array}$ & $\begin{array}{l}0 \cdot 112 \\
0 \cdot 113 \\
0 \cdot 18\end{array}$ \\
\hline $\begin{array}{l}\text { Mice given } \\
2.3 \times 10^{8} \\
\text { organisms }\end{array}$ & 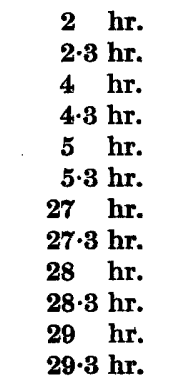 & $\begin{array}{l}4.5 \times 10^{5} \\
2.3 \times 10^{5} \\
1.9 \times 10^{6} \\
6.3 \times 10^{4} \\
1.3 \times 10^{5} \\
3.9 \times 10^{5} \\
8.3 \times 10^{2} \\
2.5 \times 10^{3} \\
1.4 \times 10^{3} \\
1.8 \times 10^{3} \\
1.5 \times 10^{3} \\
1.3 \times 10^{8}\end{array}$ & $\begin{array}{r}672 \\
624 \\
668 \\
81 \\
365 \\
204 \\
2 \\
7 \\
3 \\
14 \\
1 \\
5\end{array}$ & \begin{tabular}{r|}
$\mathbf{4 8 1}$ \\
210 \\
299 \\
174 \\
393 \\
456 \\
77 \\
$\mathbf{3 5}$ \\
$\mathbf{3 2}$ \\
$\mathbf{3 9}$ \\
$\mathbf{2 2}$ \\
$\mathbf{4 3}$
\end{tabular} & \begin{tabular}{l|}
$0 \cdot 14$ \\
$0 \cdot 148$ \\
$0 \cdot 112$ \\
$0 \cdot 233$ \\
$0 \cdot 169$ \\
$0 \cdot 172$ \\
$0 \cdot 106$ \\
$0 \cdot 082$ \\
$0 \cdot 038$ \\
$0 \cdot 154$ \\
$0 \cdot 187$ \\
$0 \cdot 074$
\end{tabular} \\
\hline
\end{tabular}

* BGPW = buffered glucose peptone water.

Table 5. $m=3 \cdot 3 ; p=9 \cdot 1 \times 10^{-4}$

\section{Source of sample}

Inoculum

Mice given

$2 \cdot 6 \times 10^{8}$

organisms
Time between inoculation and sampling (see below)*

$2 \mathrm{hr}$.
$4 \mathrm{hr}$.
$25 \mathrm{hr}$.

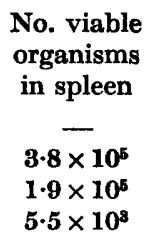

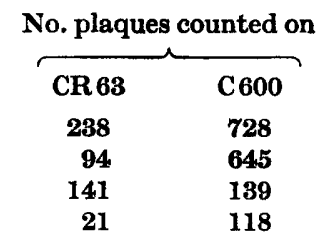

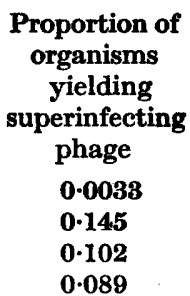

* This was an early experiment in which the inoculum was only cooled to $15^{\circ}$ while the mice were injected, instead of to $4^{\circ}$ as in later experiments. The proportion of organisms carrying superinfecting phage was measured by u.v.-irradiation of the cooled suspension and was not also determined after incubation of the inoculum in buffered glucose peptone water at $37^{\circ}$. It is supposed that at $15^{\circ}$ the bacteria were able to inactivate most of the superinfecting phage while the inoculations were being made (see also curve $B$ in Fig. 5 , and Sample 3 in Table 1).

into mice because inactivation appears to require conditions suitable for growth (Fig. 2; Table 1) whereas the viable organisms recovered from the spleen do not appear to have divided since inoculation (Tables 2-5; Fig. 7).

The proportion of organisms yielding superinfecting phage might, however, have remained constant for another reason. Cultural conditions are known to affect the rate of lysogenization of a non-lysogenic bacterium by a temperate phage (Bertani, 1958) so that the conditions in the mouse might, conceivably, have increased the rate of lysogenization of Escherichia coli strain $\mathrm{K} 12(\lambda \mathrm{b})$ by the superinfecting phage from c. 0.001 the rate observed in vitro (Fig. 4) to $c .0 \cdot 02-0 \cdot 06$, the usual probability/absorbed superinfecting phage of being 
preserved (shown in Tables 2-5 by the values of $p$ ). Phage $\lambda$ he would then have been present, not as superinfecting phage, but as prophage which would have multiplied synchronously with the bacteria. The proportion of organisms carrying phage $\lambda$ he would then not have altered, even if the bacteria had divided in vivo. This possibility was excluded by plating out colonies obtained from the viable counts in the experiment shown in Table 4. Single colonies from the subcultures were then streaked across the indicator strains, C600 and CR63, and incubated overnight at $37^{\circ}$ after u.v.-irradiation for 90 sec. About 40 colonies from the viable count on each spleen were tested, making a total of 504 colonies. None yielded phage $\lambda$ he although all yielded phage $\lambda b$. Hence, the superinfecting phage had not entered the prophage state after the bacteria had been inoculated into mice.

The number of organisms induced was usually $c .10 \%$ of the viable count and was never greater as might occur if the capacity of the organisms to yield phage after induction was more resistant to inactivation in vivo than their ability to form colonies. This may mean that loss of colony-forming ability is due to gross destruction of the bacteria and not to a bactericidal mechanism having a highly specific effect on the organisms.

\section{DISCUSSION}

The method described here for determining bacterial division rates appears to be extremely sensitive. Firstly, because $N$, the initial mean number of superinfecting phage particles preserved/stably superinfected bacterium, can be little more than 1 (Fig. 3), so that each of the early generations causes almost the maximum decrease of one half in the proportion of superinfected organisms. Secondly, because the method can be used successfully when the viable count is relatively very small. Technically the method is simple, the most laborious stage being the washing of the spleen homogenate. This might perhaps be avoided by using a chemical inducer in place of ultraviolet irradiation.

The method rests on two assumptions. The first is that the superinfecting phage will be distributed amongst bacterial progeny in the manner shown in Fig. 1, whatever the interval between divisions. This assumption could be tested by growing the organisms in different media or in a chemostat. The second assumption is that the presence of superinfecting phage does not affect the behaviour of the bacteria in vivo. This assumption was justified in the present experiments while the organisms were in the spleen, since it is very improbable that a selective effect would be counterbalanced by just that degree of multiplication needed to keep the proportion of superinfected bacteria virtually constant for $30 \mathrm{hr}$. In general, however, selection for or against superinfected organisms could only be detected either by observing that the proportion of superinfected organisms steadily rose during the infection or by measuring the division rate by an independent method.

Various other methods were considered before the present one was tested. The only alternative which seemed feasible was the inoculation of bacteria 
heavily labelled with radioactive phosphorus; the concentration of isotope, and hence the number of generations, being measured by the death rate of the organisms because of isotope decay after recovery from the animal (Fuerst \& Stent, 1956). This method is only practicable when, as in the present system, few or no divisions occur. It will be seen that no method will be generally satisfactory that is based on examination of the total (i.e. living + dead) bacterial population because, if killing occurred and produced a large number of dead organisms within a short time of inoculation, subsequent division of the surviving bacteria would produce only a negligibly small change in the composition of the total bacterial population.

The average lethal dose of Escherichia coli strain $\mathrm{K} 12$ is more than $10^{7}$ organisms by intraperitoneal injection, even when given with mucin (Rowley, 1954) so that this strain is, at the least, highly attenuated for the mouse. Tables 2-5 show that attenuation is here due to the inability of the bacteria to produce viable progeny in their host. This might occur in two ways. First, because the bacteria could not divide, either because of the presence of an inhibitor or because of the absence of an essential bacterial metabolite from the host (Hawking, 1953). (The latter explanation is unlikely since $\boldsymbol{E}$. coli, strain $\mathrm{K} 12$ is prototrophic.) Or secondly, because the organisms were able to divide in vivo but, in doing so, became phenotypically susceptible to bactericidal factors in the mouse and were invariably killed. An example of such a mechanism is provided by the bactericidal action of serum which will only kill $E$. coli once multiplication has begun (Rowley \& Wardlaw, 1958). On this view, the viable counts on the spleen (Fig. 6) give the number of organisms which had not divided since inoculation.

I wish to thank Dr Werner Arber for some of the cultures and phages used in these experiments, and the Medical Research Council for a grant towards the expenses of this work.

\section{REFERENCES}

Adams, M. H. (1959). Bacteriophages. New York: Interscience Publishers, Inc.

APpleYard, R. K., McGregor, J. F. \& BaIrD, K. M. (1956). Mutation to extended host range and the occurrence of phenotypic mixing in the temperate coliphage lambda. Virology, 2, 565.

Atwood, K. C. \& Norman, A. (1949). On the interpretation of multi-hit survival curves. Proc. nat. Acad. Sci., Wash. 35, 696.

Bertant, G. (1953). Lysogenic versus lytic cycle of phage multiplication. Cold Spr. Harb. Symp. quant. Biol. 18, 65.

Bertani, G. (1954). Studies on lysogenesis. III. Superinfection of lysogenic Shigella dysenteriae with temperate mutants of the carried phage. J. Bact. 67, 696.

Bertant, G. (1958). Lysogeny. Advanc. Virus Research, 5, 151.

FUERST, C. R., \& STENT, G. S. (1956). Inactivation of bacteria by decay of incorporated radioactive phosphorus. J. gen. Physiol. 40, 73.

HAwkING, F. (1958). Milk diet, $p$-aminobenzoic acid, and malaria (P. berghei). Brit. med. J. i, 1201.

$\mathrm{J}_{\mathrm{ACOB}}$, F. (1954). Les Bactéries Lysogènes et la Notion de Provirus. Paris: Masson.

$\mathrm{J}_{\mathrm{ACOB}}, \mathbf{F}$. \& Wollman, E. (1953). Induction of phage development in lysogenic bacteria. Cold Spr. Harb. Symp. quant. Biol. 18, 101. 
LIEB, M. (1953). The establishment of lysogenicity in Escherichia coli. J. Bact. 65, 642.

Lworf, A. (1953). Lysogeny. Bact. Rev. 17, 269.

Lwoff, A., Siminovitch, L. \& KJELdgaARd (1950). Induction de la production de bactériophages chez une bactérie lysogène. Ann. Inst. Pasteur, 79, 815.

Meynell, G. G. \& MeYnell, E. W. (1958). The growth of micro-organisms in vivo with particular reference to the relation between dose and latent period. J. Hyg., Camb. 56, 323.

Rowley, D. (1954). The virulence of strains of Bacterium coli for mice. Brit. J. exp. Path. 35, 528.

Rowley, D. \& WARDLAW, A. C. (1958). Lysis of Gram-negative bacteria by serum. J. gen. Microbiol. 18, 529.

Weigle, J. J. \& Det.raück, M. (1951). Mutual exclusion between an infecting phage and a carried phage. J. Bact. 62, 301.

(Received 13 April 1959) 